\title{
Kesiapan Sarana Prasarana dalam Meningkatkan Mutu Pendidikan untuk Menghadapi Revousi Industri 4.0
}

\author{
Iis Nawati; Arief Sadjiarto; Lelahester Rina
}

\author{
Universitas Kristen Satya Wacana \\ Jalan Diponegoro No. 52-60 Salatiga Jawa Tengah Indonesia \\ 162016004@student.uksw.edu
}

Article received: July 2020; revised : October 2020 ; accepted : February 2021

DOI : 10.17977/um025v5i12020p41

\begin{abstract}
This study aims to determine the readiness of facilities and infrastructure in improving the quality of education to face the industrial revolution 4.0. The research used a qualitative descriptive approach at SMP Pangudi Luhur Salatiga. In this study, the analysis unit was used, namely facilities and infrastructure, while the observation unit was the principal, deputy head of the facilities and infrastructure sector, and educators. Data collection techniques using observation, interviews, questionnaires, and documentation using triangulation techniques. Meanwhile, data analysis was carried out interactively with data collection, data reduction, data presentation, and drawing conclusions. Conclusions from the study: (1) the planning of facilities and infrastructure has been carried out well; (2) the procurement of facilities and infrastructure has not been carried out properly, the priority scale is determined by the foundation not the school; (3) the maintenance of facilities and infrastructure has not been carried out optimally; (4) the elimination of facilities and infrastructure has never been carried out by schools, items that are no longer used are put into school warehouses; and (5) there are developments in facilities and infrastructure in the field of technology, while the human resources that are owned are still not professionally trained.
\end{abstract}

Keywords: facilities and infrastructure; quality education; revolution industry 4.0

\begin{abstract}
Abstrak: Penelitian ini bertujuan untuk mengetahui kesiapan sarana dan prasarana dalam meningkatkan mutu pendidikan untuk menghadapi revolusi industri 4.0. Penelitian menggunakan pendekatan deskriptif kualitatif di SMP Pangudi Luhur Salatiga. Pada penelitian ini menggunakan unit analisis yaitu sarana prasarana, sedangkan yang menjadi unit pengamatan yaitu kepala sekolah, wakil kepala bidang sarana dan prasarana, dan pendidik. Teknik pengumpulan data menggunakan pengamatan, wawancara, angket, dan dokumentasi dengan menggunakan teknik triangulasi. Sedangkan analisis data dilakukan secara interaktif dengan pengumpulan data, reduksi data, penyajian data, dan penarikan kesimpulan. Simpulan dari penelitian: (1) perencanaan sarana dan prasarana sudah dilakukan dengan baik; (2) pengadaan sarana dan prasarana belum dilakukan dengan baik skala prioritas ditentukan oleh yayasan bukan pada sekolah; (3) pemeliharaan sarana dan prasarana belum dilakukan secara optimal; (4) penghapusan sarana dan prasarana belum pernah dilakukan oleh sekolah barang yang sudah tidak digunakan dimasukkan kedalam gudang sekolah; dan (5) adanya perkembangan sarana dan prasarana dalam bidang teknologi, sedangkan sumber daya manusia yang dimiliki masih belum yang terlatih secara profesional.
\end{abstract}

Kata kunci: sarana prasarana; mutu pendidikan; revolusi industri 4.0

Dunia pendidikan sekarang ini tidak seperti pendidikan pada era sebelumnya. Pada era revolusi saat ini, seluruh lapisan kehidupan telah berubah keteknologi dengan ditandai oleh meningkatnya interaksi, hubungan antar sesama, serta perkembangan terhadap sistem digital. Hal tersebut menjadikan semakin terpusatnya batas antara manusia dan mesin dan juga akan berpengaruh pada sistem pendidikan yang ada di Indonesia. Menurut Maysitoh, Agung, dan Afdal (2018) pendidikan sekarang ini memiliki perubahan pada saat kegiatan belajar mengajar dengan munculnya teknologi sebagai media yang digunakan untuk mempermudah manusia dalam bekerja. Pada era yang telah berubah pada saat ini, tidak bisa dihindari namun membutuhkan kualitas sumber daya manusia agar bisa bersaing di dunia luar. Menurut Yuliati dan Saputra (2019) perubahan teknologi sekarang ini, peserta didik dituntut untuk bisa memiliki keahlian 
yang lebih dan kemampuan dalam memecahkan masalah seperti berpikir kritis, kreatif, inovatif, dapat bekerjasama, berkolaborasi, dan tingkat percaya diri, serta memiliki kemampuan dalam berkomunikasi. Pada pencapaian salah satunya dengan cara mengoptimalkan penggunaan media sebagai pendukung dunia pendidikan serta menghasilkan lulusan berkualitas yang memiliki kemampuan dalam mengikuti perkembangan zaman sesuai dengan tuntutan teknologi. Namun dalam proses menyiapkan sumber daya manusia, diperlukan pendidikan dasar dan menengah agar dapat berjalan sesuai tujuan. Menurut Heri (2019) pendidikan akan mencetak calon generasi yang memiliki ketangguhan, serta berdaya saing tinggi.

Pada revolusi industri 4.0 ditandai dengan kecerdasan buatan mesin yang memiliki teknologi canggih dan inovasi. Perubahan seperti ini akan berdampak pada dunia industri seperti ekonomi, pendidikan, dan pemerintahan. Menurut Savitri (2019) mulainya revolusi industri ditandai dengan adanya peralatan yang mendukung seperti mesin uap, maka disebut dengan era revolusi industri 1.0. perubahan kembali terjadi dengan munculnya pabrik-pabrik dengan berbasis energi listrik, yang sering disebut dengan 2.0. pada masa revolusi industri 3.0 pabrik menggunakan teknologi dalam proses produksi. Menurut Yuliati dan Saputra (2019) revolusi industri 4.0 sebagai era pada tingkat persaingan yang tingi, karena kehidupan setiap orang selalu berkaitan dengan teknologi informasi. Pada era sekarang ini dapat memberikan perubahan yang cukup nyata terhadap pola kehidupan setiap individu. Bahkan setiap orang dapat mengerjakan aktivitas dengan mudah, cepat, dan praktis. Meskinpun dengan kemunculan teknologi juga dapat memberikan dampak baik positif maupun negatif dari berbagai aspek kehidupan seperti kejahatan dan sumber daya manusia

Era globalisasi menuntut pendidikan memilikikualitas yang baik dan mampu membawa tantangan dan perubahan dari berbagai kalangan. Menurut Rahayu dan Sutama (2015); Priansa dan Garnida (2015) kualitas peserta didik yang baik, tidak akan lepas dari pengelolaan fasilitas sekolah berupa pengadaan, pemeliharaan, serta melakukan perbaikan. Penentuan sekolah dalam keadaan pengelolaan efektif atau tidak, hal ini hanya bisa ditentukan oleh kerjasama tenaga pendidik dan tenaga kependidikan yang terjun langsung di lapangan dan paling mengetahui kondisi yang ada. Namun manajemen sarana prasarana sekolah menjadi acuan yang sangat penting dalam menjaga dan mengatur sarana prasarana pendidikan agar bisa berjalan dengan optimal, sehingga menciptakan suasana sekolah yang menyenangkan bagi pendidik, tenaga kependidikan, maupun peserta didik.

Peraturan Pemerintah Nomor 19 Tahun 2005 tentang Standar Nasional Pendidikan yang menyangkut tentang standar sarana prasarana disebutkan bahwa: (1) setiap satu pendidikan wajib memiliki sarana prasarana yang meliputi perabot, peralatan pendidikan, media pendidikan, buku, dan sumber belajar lainnya, bahan habis pakai, serta perlengkapan lain yang diperlukan untuk menunjang proses pembelajran yang teratur dan berkelanjutan; dan (2) setiap satuan pendidikan wajib memilii prasarana yang meliputi lahan, kelas, ruang pimpinan satuan pendidikan, ruang tata usaha, ruang perpustakaan, ruang laboratorium, ruang bengkel kerja, ruang unit produksi, ruang kantin, instanlasi daya dan jasa, tempat berolahraga, tempat ibadah, tempat bermain, tempat beraksi, dan ruang/tempat lain yang diperlukan untuk menunjang proses pembelajaran yang teratur dan berkelanjutan.

Fasilitas sebagai pelegkap yang memiliki peran penting dalam instansi ataupun lembaga pendidikan. Sekolah yang mempunyai perlengkapan dan peralatan lengkap serta mendukung pada saat proses pembelajaran akan menambah nilai plus bagi sekolah. Menurut Priansa (2015) sarana merupakan peralatan secara langsung terhubung saat proses kegiatan belajar mengajar dalam mencapai tujuan pembelajaran. Sarana akan mendukung proses pembelajaran dan meningkatkan mutu pendidikan karena fasilitas sekolah yang lengkap menjadi penentu kualitas siswa. Sedangkan menurut Rahayu dan Sutama (2015) mengemukan bahwa sarana pendidikan sebagai peralatan yang berhubungan secara langsung dengan pesera didik dan dapat digunakan pada proses pembelajaran yaitu seperti buku, laboratorium, dan perpustakaan.

Adapun prasarana merupakan perlengkapan sebagai penunjang proses pembelajaran, prasarana sangat penting sebagai alat untuk menunjang jalannya proses pembelajaran menjadi lebih baik. Menurut Govinav (2014) prasarana merupakan segala perlengkapan yang digunakan untuk terlaksananya proses pembelajaran yang dilakukan seperti didalam kelas maupun pada saat proses pembelajaran berada di 
luar kelas. Ketika melakukan pembelajaran yang secara tidak langsung peserta didik menggunakan perlengkapan prasarana sekolah, maka itu perlengkapan sekolah harus baik agar supaya peserta didik bisa menggunakan sebagaimana mestinya untuk penunjang proses pembelajaran. Sedangkan menurut Hartoni, Amirudin, \& Subandi (2018) dan Rahayu \& Sutama (2015) prasarana merupakan fasilitas yang digunakan oleh peserta didik secara tidak langsung sebagai menunjang kegiatan belajar mengajar seperti lapangan, ruangan, dan lokasi, bangunan sekolah. Fasilitas seperti ini akan selalu digunakan oleh peserta didik dalam berlangsung kegiatan belajar mengajar yang menunjang tujuan dari pembelajaran.

Sarana dan prasarana merupakan delapan standar nasional pendidikan yang memiliki bagian penting bagi sekolah. Sekolah menyediakan perlengkapan dan peralatan sekolah dengan tujuan untuk meningkatkan mutu sekolah agar proses belajar mengajar berjalan sebagaimana seharusnya. Bukan hanya itu, fasilitas sarana prasarana akan menjadi daya tarik bagi calon peserta didik walaupun bukan menjadi prioritas utama. Sarana prasarana tidak hanya berbentuk fisik seperti bangunan, taman, toilet, laboratorium, ruangan kepala sekolah, dan ruangan tata usaha, akan tetapi dapat juga berbentuk non-fisik seperti bersih, rapi, dan tenang. Namun semua fasilitas tidak dapat mendukung secara optimal apabila sekolah tidak mampu memanfaatkannya sebagai contoh gedung sekolah yang memiliki kualitas baik akan tetapi tidak dilakukan perawatan, alat peraga tidak dimanfaatkan atau digunakan dengan maksimal, dan sejumlah permasalahan fasilitas yang belum digunakan dengan baik. Proses pembelajaran yang baik akan memerlukan perlengkapan dan peralatan sebagai fasilitas pembelajaran yang digunakan secara optimal. Ketersedian fasilitas sekolah akan memberikan masukan dalam proses pembelajaran secara optimal.

Memberikan pelayanan kepada konsumen tidak lepas dari pengelolaan dan proses dalam memberikan nilai tambah kepada pihak yang berproses untuk meningkatkan kualiatas kebutuhan dengan efisien dan efektif. Menurut Rahman (2012) mutu merupakan tingkatan keunggulan produk yang berkaitan dengan pelayanan. Minarti (2017) perubahan sekolah yang baik harus diawali dengan komitmen bersama, dalam hal ini seperti komite sekolah, administrator, tenaga pendidik, tenaga kependidikan, peserta didik, dan orangg tua. Mutu sebagai tolak ukur keberhasilan sekolah dalam memenuhi kebutuhan siswa dalam pembelajaran. Perdana (2019) mengungkapkan kualitas pendidikan akan memberikan kontribusi dalam mengelola kemampuan sumber daya manusia dengan efektif dan efisien. Kemampuan dalam memberikan kualitas sumber daya manusia. maka sekolah kemampuan yang kuat serta daya saing tinggi. Menurut Fadhli (2017) pada pandangan secara makro banyak hal yang bisa mempengaruhi kaulitas pendidikan seperti kurikulum, kebijakan sekolah, fasilitas sekolah, biaya pendidikan yang standar, memiliki cara evaluasi yang sesuai, strategi dan pendekatan pendidikan sesuai dengan zaman, serta sumber daya manusia yang terlatih, profesional, pengalaman, dan memiliki pengetahuan luas.

SMP Pangudi Luhur Salatiga salah satu sekolah katolik swasta yang berada di Salatiga sekolah ini di dirikan oleh Yayasan Pangudi Luhur. Dari observasi ditemukan fenomena sebagai berikut yaitu salah satu ruang kelas yang tidak digunakan dalam proses belajar mengajar, padahal ruangan itu besar namun tidak terawat, dan ruangan berada disamping atau di belakang kelas. Jika ada komputer yang terdapat rusak, maka perbaikan tidak bisa dilakukan secara langsung akan tetapi memerlukan waktu perbaikan satu bulan setelah kerusakan itu, sehingga akan menghambat proses pembelajaran khususnya pada mata pelajaran teknologi informasi komputer. Pada ruangan laboratorium ilmu pengetahuan alam tidak dipasang LCD. Kantin sekolah berada pojok paling samping, kantin tersebut warna cat yang kusam. Tujuan dari penelitian ini merupakan untuk mengetahui kesiapan sarana dan prasarana dalam meningkatkan mutu pendidikan untuk menghadapi revolusi industri 4.0.

\section{METODE}

Pendekatan yang digunakan dalam penelitian ini yaitu pendekatan kualitatif. Menurut Sugiono (2012) penelitian kualitatif merupakan penelitian yang digunakan untuk mengetahui kondisi obyek secara alamiah, penelitian ini bersifat deskriptif. Data yang dikumpulkan berupa kata-kata, gambar, dan bukan angka (Moleong, 2010). 
Instrumen yang digunakan dalam penelitian adalah orang yang melakukan penelitian itu sendiri (Sugiono, 2015). Sedangkan instrumen pendukung lainnya seperti paduan wawancara yang merupakan paduan peneliti melakukan waawancara dengan narasumber, analisis trianguasi menurut Moleong (2010) merupakan cara yang tepat sebagai bukti yang menghilangkan perbedaan pada pola dalam bagian kajian, diwaktu mengumpulkan data dari sumber informasi yang berbeda atau membandingkan temuan yang telah ada. Alat perekam juga digunakan sebagai pendukung peneliti dalam pengumpulan data, pengelolaan data, maupun penyimpana data. Data diperoleh melalui penelitian seperti observasi, dokumentasi, interview, dan studi pustaka.

Analisis data menggunakan analisis triangulasi dengan triangulasi sumber dan triangulasi teknik. Menurut Sugiono (2015) mengemukan bahwa triangulasi sumber merupakan teknik yang digunakan dalam menguji kredibilitas data dengan cara mengecek sumber data dari beberapa sumber. Sedangkan triangulasi teknik merupakan teknik yang digunakan yang digunakan dalam menguji kredibilitas data dengan cara mengecek data dari sumber yang sama akan tetapi dengan teknik yang beda (Sugiono, 2015). Berikut ini dapat digambar tentang sumber mendalam (Gambar 1, Gambar 2).

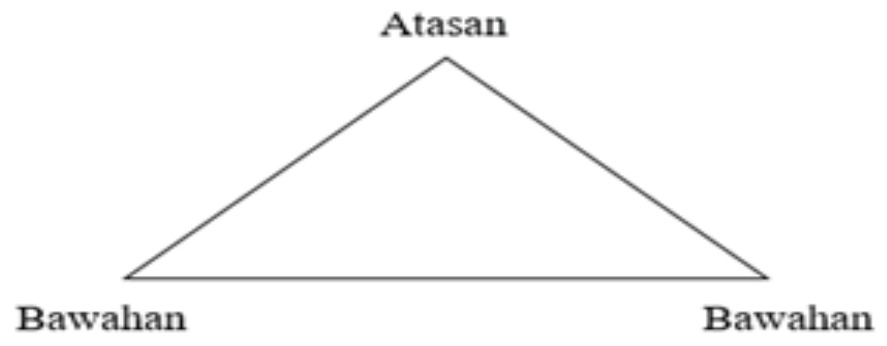

Gambar 1 Triangulasi Sumber Data (Sugiono, 2015)

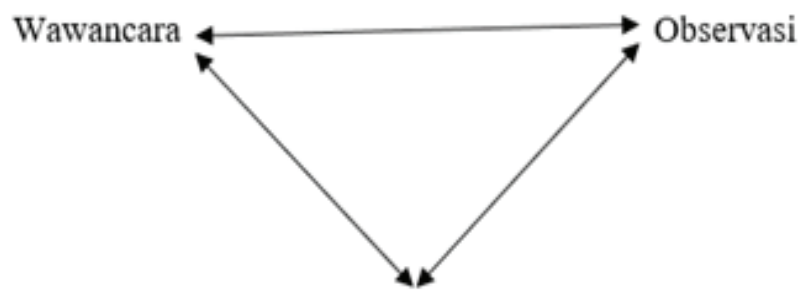

Kuesioner/dokumen

Gambar 2 Triangulasi Teknik Pengumpulan Data (Sugiono, 2015)

\section{HASIL DAN PEMBAHASAN}

\section{Sarana dan Prasarana}

Berdasarkan observasi dan wawancara ditemukan hasil penelitian yang diilustrasikan pada Gambar 3. Mewujudkan fasilitas sekolah yang baik dalam bentuk penunjang mutu pendidikan di era revolusi industri 4.0. fasilitas sekolah salah satu hal yang paling penting untuk kenyamanan dan kelengkapan sebagai penunjang belajar mengajar bagi peserta didik. Fasilitas yang dimiliki sekolah seperti ruang aula, wc, ruang guru, ruang pimpinan, TU, ruang tamu, kelas, ruang doa, kantin, lapangan basket, lapangan volly, lapangan bola kaki, perpustakaan, laboratorium komputer, laboratorium IPA, dan tempat parkir. Berdasarkan hasil wawancara yang dilakukan di SMP Pangudi Luhur Salatiga terkait sarana dan prasarana dapat dipaparkan sebagai berikut: 


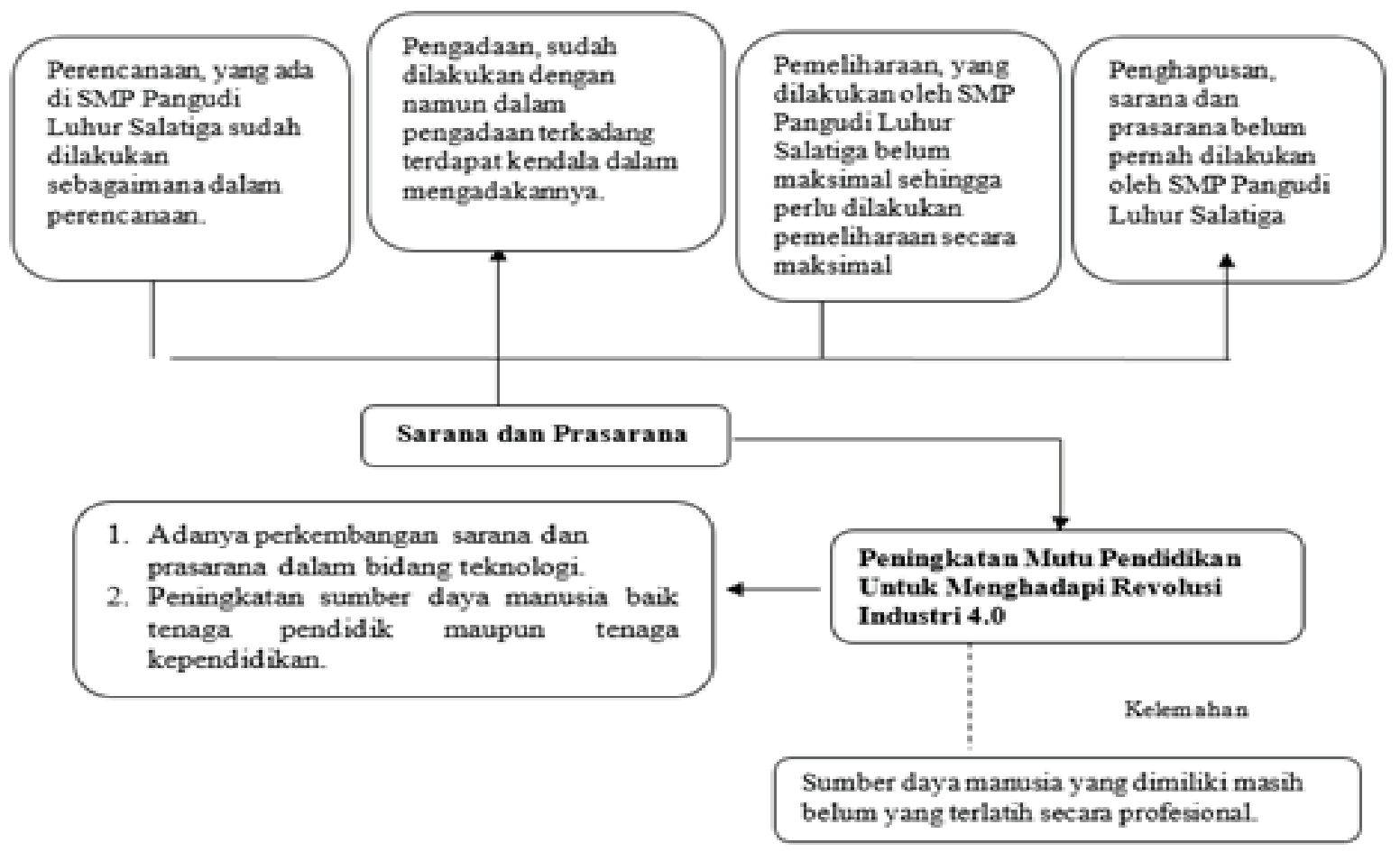

\section{Gambar 3 Penggunaan Sarana dan Prasarana dalam Meningkatkan Mutu Pendidikan SMP Pangudi Luhur Salatiga}

Perencanaan, sebagai proses perencanaan fasilitas sekolah dilakukan oleh seluruh warga sekolah baik tenaga pendidik dan tenaga kependidikan. Pada proses pembuatan rancangan fasilitas oleh pihak sekolah sangat memperhatikan kebutuhan mana yang paling prioritas oleh sekolah. Sehingga dalam proses pengajuan ke yayasan oleh kepala sekolah, kepala sekolah sudah memperhitungkan skala prioritas yang bisa menjadi pertimbangan oleh yayasan. Tahap perencanaan sarana dan prasarana biasanya bapak ibu guru diminta untuk membuat daftar kebutuhan dalam satu tahun. Setiap bapak ibu guru membuat daftar kebutuhan selama 1 tahun yang nantinya akan di susun oleh bendahara dan kepala sekolah untuk di usulkan kepada yayasan.

Pengadaan, fasilitas di SMP Pangudi Luhur Salatiga dilakukan berdasarkan tingkat kepentingan dan skala prioritas sekolah. Sehingga dalam proses pengajuan fasilitas bisa mendukung proses kegiatan belajar mengajar, kegiatan ekstra, maupun kegiatan pimpinan. Proses pengadaan sarana dan prasarana sekolah, sekolah lebih mementingkan skala prioriras paling utama yang mana dalam proses pengajuan kepada yayasan, yayasan langsung menentukan sendiri skala prioritasnya.

Pemeliharaan masih menjadi kelemahan SMP Pangudi Luhur Salatiga, sekolah dan belum bisa secara penuh melakukan pengecekan terutama pada sarana dan prasarana elektronik, ketika ada masalah baru dilakukan perbaikan namun dalam melakukan perbaikanpun tergantung dengan situasinya yang paling mendesak. Namun dalam melakukan pemeliharaaan sarana dan prasarana baru akan dilaksanakan pada saat adanya laporan dari tenaga pendidik maupun tenaga kependidikan. Ketika ada laporan bahwa ada internet tidak berfungsi dengan baik, maka baru akan dilakukan permeliharaan. Sehingga pemeliharaan tidak dilakukan secara langsung tetapi secara bertahap. Dan yang menjadi masalah ketika melakukan pemeliharaan adalah kurang baik dalam menyampaikan pesan antar sesama tenaga pendidik dan tenaga kependidikan.

Penghapusan, belum pernah dilakukan oleh sekolah sekolah. Barang yang sudah rusak atau sudah tidak berfungsi lagi maka akan disimpan didalam gudang. Misalnya prasarana seperti printer dan CPU yang sudah tidak digunakan, maka akan digudangkan. 
Kelengkapan fasilitas sekolah menjadi bagian paling penting dalam meningkatkan kualitas pembelajaran. Menunjang kualitas pembelajaran salah satu upaya yang dilakukan sekolah menyediakan fasilitas yang lengkap. Fasilitas yang lengkap tidak akan lepas dari perencanaan yang baik, pengadaan yang sesuai dengan perencanaan, pemeliharaan yang dilakukan secara rutin, dan melakukan penghapusan agar fasilitas yang tidak berfungsi menjadi tidak menumpuk dalam satu ruangan. Namun yang sudah diterapkan pada SMP Pangudi Luhur Salatiga tidak seperti adanya, dijelaskan sebagai berikut:

Perencanaan ketersedian fasilitas yang memadai salah satu bentuk penunjang bagi sekolah untuk meningkatkan kualitas. Langkah awal yang diterapkan oleh sekolah yaitu menyediakan fasilitas dengan membuat sebuah perencanaan yang dibutuhkan oleh sekolah. Dalam pengadaan fasilitas sekolah melibatkan seluruh karyawan yang terlibat dalam menunjang pembelajaran di SMP Pangudi Luhur Salatiga. Rancangan dalam pembuatan sebuah perencanaan merupakan patokan mendasar sebagai tolak ukur dalam menentukan keberhasilan program yang akan dilaksanakan sekolah selama 1 periode. Hal ini sesuai dengan Barnawi dan Arifin (2017) mengatakan membuat kerangka perencanaan pengadaan fasilitas untuk proses pembelajaran tahun berikutnya. Pada proses perencanaan yang baik dapat menentukan keberhasilan pada program sekolah yang telah di buat dimana ketersediaan sarana dan prasarana dapat menentukan mutu pendidikan. Menurut Muhammad dan Rahman (2017) merupakan suatu alat penunjang pada keberhasilan pendidikan maka diperlukan pengelolaan yang tapat oleh sekolah. Hal ini berarti bahwa pendidikan dapat dikatakan berhasil apabila dilakukan dan dilaksanakan dengan baik oleh pihak sekolah agar tujuan berjalan sebagaimana mestinya. Salah satu bentuk usaha sekolah dalam meningkatkan kualitas adalah tersedianya fasilitas yang memadai sebagai penunjang pendidikan yang sesuai dengan tujuan. Langkah awal harus di tentukan ketika melakukan pengadaan fasilitas yang dibutuhkan oleh sekolah yaitu mmebuat sebuah perencanaan. Perencanaan sarana dan prasarana di SMP Pangudi Luhur Salatiga merupakan pemikiran semua warga sekolah dalam membuat program sebagai acuan suatu rancangan pengadaan fasilitas sekolah agar tecapainya tujuan pendidikan, perencanaan fasilitas sekolah dilakukan agar peserta didik mampu dan terampil. Pada perencanaan pengadaan sarana dan prasarana sekolah sangat memperhatikan permendiknas nomor 19 tahun 2005 tentang standar nasional pendidikan yang dilaksanakan sebagai pedoman dalam mengadakan sarana dan prasarana sekolah yang dibutuhkan. Hal ini juga ditegaskan oleh Cahyono, Budiwibowo, dan Murwani (2015) mengatakan bahwa sekolah meski membuat sebuah perencanan, mengadakan sosialisai, serta melakukan evaluasi kegiatan, dan membuat sebuah tindakan.

Pengadaan tahap setelah pembuatan perencanaan, selanjutnya proses pengadaan sarana dan prasarana. Hasil wawancara yang dilakukan di SMP Pangudi Luhur Salatiga yaitu pihak sekolah melakukan rapat bersama dewan guru kemudian pengajuan kepada yayasan. Hal ini sudah sesuai dengan teori Barnawin dan Arifin (2017) mengatakan bahwa pengadaan dilakukan guna untuk merealisasikan perencanaan yang telah dilakukan. Namun juga didukung dengan penelitian Rahayu dan Sutama (2015) yaitu proses pengadaan dilakukan dengan musyawarah bersama kelompok pengembang sekolah. Hasil wawancara tidak sesuai dengan dilapangan dimana pengadaan dilakukan atas dasar persetujuan yayasan dan diadakan berdasarkan skala prioritas keperluan yang ditentukan oleh yayasan bukan sekolah.

Pemeliharaan kegiatan yang dilakukan oleh sekolah untuk menjaga keutuhan dari perlengkapan dan peralatan ketika diperlukan oleh tenaga pendidik maupun tenaga pendidik selalu dalam kondisi yang baik. Pada kesiapan sarana dan prasarana yang baik membantu kelancaran pada kegiatan pembelajaran di sekolah. Pemeliharaan fasilitas sekolah sangat membantu kegiatan didalam kelas maupun di luar kelas. Hasil wawancara yang dilakukan di SMP Pangudi Luhur Salatiga bahwa pemeliharaan dilakukan ketika peralatan tidak bisa digunakan namun tidak diperbaiki secara cepat, sehingga kegiatan pembelajaran menjadi tidak efektif dan efisien. Hal ini sesuai dengan teori pemeliharaan menurut Minarti (2017) mengatakan pemeliharaan adalah kegiatan mengurus dan mengatur perlengkapan dan peralatan sekolah agar berfungsi dengan baik. Hal ini juga didukung oleh penelitian Suryani (2017) mengungkapkan bahwa pemeliharaan perlu dilakukan secara teratur agar fasilitas yang tidak mudah rapuh dan menjadi awet.

Penghapusan kegiatan yang dilakukan oleh sekolah untuk meniadaakan atau menghilangkan barangbarang yang sudah tidak berfungsi sebagaimana mestinya dalam kegiatan belajar mengajar maupun 
dalam kegiatan yang menunjang proses penyelesaian tugas oleh pendidik maupun tenaga pendidik. Penghapusan di SMP Pangudi Luhur Salatiga belum pernah dilakukan, namun barang-barang sudah tidak berguna atau tidak berfungsi dengan baik hanya dimasukkan ke dalam gudang dan membuat salah satu kelas penuh dengan tumpukkan buku-buku yang sudah tidak digunakan. Hal ini tidak sesuai dengan teori penghapusan menurut Barnawi dan Arifin (2017) merupakan kegiatan yang memiliki tujuan untuk menghapus atau mengeluarkan sarana dan prasarana dari daftar inventaris hal ini dilakukan untuk mengurangi fasilitas yang sudah tidak berfungsi lagi terutama bagi kepentingan kegiatan pembelajaran. Hal ini sejalan dengan penelitian yang dilakukan oleh Kurniawati dan. Sayuti (2013) dan Tanggela (2013) yang mengatakan bahwa belum pernah melakukan penghapusan barang oleh pihak sekolah.

Berdasarkan dari keempat bagian dari sarana dan prasarana yang terdiri dari perencanaan, pengadaan, pemeliharaan, dan penghapusan hal yang paling nampak yaitu perencanaan. Perencanaan merupakan bagian yang paling baik dari ketiga bagian yang ada. Pada kegiatan perencanaan yang ada di SMP Pangudi Luhur Salatiga yaitu terdiri dari rapat pendidik maupun tenaga kependidikan, pembuatan rancangan selama 1 Tahun, pembuatan proposal, serta sampai pada kegiatan pengajuan kepada yayasan sekolah. Oleh karena itu, perencaan dapat dikatakan paling baik karena paling urut dan sesuai dengan teori.

\section{Peningkatan Mutu Pendidikan untuk Menghadapi Revolusi Industri 4.0}

Dalam meningkatkan mutu sekolah, pihak sekolah juga memiliki supervisi yang dilakukan selama 2 kali dalam setahun. sekolah juga sudah melengkapi sarana dan prasarana siswa dalam mencari informasi melalui internet, seperti wi-fi. Sumber daya manusia yang dimiliki oleh SMP Pangudi Luhur Salatiga masih perlu banyak belajar dalam penggunaan sarana prasarana yang ada terutama teknologi, keinginan untuk belajar timbul apabila adanya paksaan yaitu pada saat akan menggunakan teknologi. Sekolah lebih memfokuskan kepada karakter anak, hal ini dilakukan agar peserta didik bisa menggunakan teknologi dengan bijak dan benar. Namun sekolah perlu melakukan peningkatan kemampuan guru yang berkaitan dengan pengoperasi IT dibidang online misal nya kemampuan dalam membuat soal secara online berupa google form ataupun media yang digunakan untuk membuat soal secara online, sebelum ada nya pandemi virus dorongan dewan guru untuk menggunakan media online, tidak sekuat seperti saat ini, situasi seperti saat ini memaksa bapak ibu guru untuk menggunakan media online.

Peningkatan mutu dilakukan di SMP Pangudi Luhur Salatiga dengan mengadakan pelatihanpalatihan kepada dewan guru. Dewan guru yang memiliki kemampuan yang kompetensi dalam mengajar akan dapat meningkatkan mutu pembelajaran. Sekolah selalu berupaya dalam meningkatkan mutu pendidikan agar mampu bersaing dengan sekolah yang lain. Hal ini sejalan dengan Gojali dan Umiarso (2012) mengungkapkan bahwa mutu pendidikan kepentingan sekolah yang menjadi keperluan utama bersaing dalam rangkan meningkatkan mutu sekolah. Peningkatan mutu pendidikan yang dilakukan oleh SMP Pangudi Luhur Salatiga dalam upaya sarana prasarana sudah dilakukan dengan cukup baik karena kepala sekolah selalu mendukung apa yang menjadi kebutuhan oleh pendidik maupun tenaga pendidik. Berdasarkan hasil penelitian menunukkan bahwa sekolah selalu mendukung semua yang bapak ibu guru ajukan, sekolah juga biasanya mengirim maupun mengadakan pelatihan untuk meningkatkan kualitas pendidik. Hal ini juga dinyatakan oleh peserta didik mengatakan bahwa fasilitas sekolah yang telah ada sudah di rasa sudah memuaskan dan dirasa nyaman ketika belajar.

Sumber daya manusia yang dimiliki oleh SMP Pangudi Luhur Salatiga belum secara maksimal mengikuti perkembangan era sekarang ini, dibuktikan dengan bapak ibu guru belum bisa menggunakan google form. Hal ini tidak sejalan dengan Yulanti dan Saputra (2019) mengatakan bahwa era revolusi sekarang ini merupakan masa yang penuh dengan persaingan dimana kehidupan manusia selalu berkaitan dengan teknologi dan informasi. Juga didukung oleh Menurut Sedana (2019) mengatakan bahwa revolusi industri merupakan era dimana dunia digital telah menjadi suatu paradigma dan acuan dalam tantanan bagi kehidupan saat ini. Sehingga sumber daya manusia yang dimiliki perlu diperbaiki agar bisa menggunakan fasilitas disekolah dengan baik. Pada proses pelaksanaan mengikuti 
perkembangan teknologi yang dilakukan oleh SMP Pangudi Luhur Salatiga sumber daya manusianya belum maksimal mengikuti perkembangan teknologi yang ada, akan tetapi dengan adanya kondisi seperti covid-19 saat ini menuntut mereka untuk menggunakan media pembelajaran secara online. Namun hal ini dilakukan karena adanya tuntutan belajar secara online sedangkan jika tidak adanya kondisi covid-19 maka pembelajaran hanya berpaku kepada guru, padahal teknologi seperti media pembelajaran LCD yang ada harus digunakan dan diikuti agar tidak ketinggalan dengan perkembangan. Dorongan untuk menggunakan teknologi tidak sekuat seperti saat ini, situasi saat ini membuat para guru harus menggunakan teknologi dalam kegiatan belajar mengajar sehingga sumber daya manusia yang dimiliki perlu diperbaiki agar bisa menggunakan sarana dan prasarana yang ada disekolah dengan baik. Hal ini didukung dengan penelitian Cahyono, Budiwibowo, dan Murwani (2015) mengatakan bahwa keterbatasan alokasi dana, sumber daya manusia muupun peserta didik, tenaga pendidik, serta tenaga kependidikan untuk memenuhi unsur dari standar nasional pendidikan seperti memberikan pelatihan dan menyediakan workshop kepada tenaga kedidik dan tenaga kependidikan

\section{SIMPULAN}

Berdasarkan hasil dari penelitian mengenai kesiapan sarana dan prasarana dalam meningkatkan mutu pendidikan untuk menghadapi revolusi industri 4.0, yaitu: (1) perencanaan sudah dilakukan dengan baik karena dalam proses perencanaan pengadaan sarana dan prasarana sekolah, (2) pengadaan belum dilakukan dengan baik karena pada proses pengajuan pengadaan sarana dan prasarana ditentukan oleh skala prioritas yayasan bukan pada sekolah, (3) pemeliharaan belum dilaksanakan secara maksimal karena hanya akan dilakukan pada kepentingan pemeliharaan yang paling mendesak, (4) penghapusan belum pernah dilakukan karena barang-barang yang sudah tidak digunakan dimasukkan ke dalam gudang sekolah sehingga terjadi penumpukan; dan (5) Peningkatan mutu untuk menghadapi revolusi industri 4.0 melalui perkembangan sarana dan prasarana dalam bidang teknologi dan peningkatan sumber daya manusia baik tenaga pendidik maupun tenaga kependidikan. Meskipun dalam pelaksanaannya sumber daya manusia yang dimiliki masih belum yang terlatih secara profesional.

\section{DAFTAR RUJUKAN}

Barnawi, \& Arifin, M. (Yogyakarta). Manajemen Sarana dan Prasarana Sekolah. 2017: AR-RUZZ Media.

Cahyono, L. E., Budiwibowo, s., \& Murwani, J. 2015. Analisis Penerapan 8 Standar Nasional Pendidikan pada SMP Negeri 2 Dolopo Kabupaten Madiun. Jurnal Akuntansi dan Pendidikan, Vol 4 No 2 Hal 99-105.

Fadhli, M. 2017. Manajemen Peningkatan Mutu. Jurnal Studi Manajemen Pendidikan, Vol 1 No 2 Hal 215-240.

Gavinov, I. T. 2016. Manajemen Perkantoran. Yogyakarta: Parana Publishing.

Hartoni, Amirudin, \& Subandi. 2018. Implementasi Manajemen Sarana Prasarana di Sekolah Menengah Kejuruan. Jurnal Kependidikan Islam, Vol 8 No 1 Hal 1-8.

Heri, E. I. 2019. Tantangan Pengembangan SDM Polri di Era Revolusi Industri 4.0. Jurnal Ilmu Kepolisian, Vol 13 No 2 Hal 90-105.

Kurniawati, P. I., \& Sayuti, S. A. 2013. Manajemen Sarana Prasarana Di SMK N 1 Kasihan Bantul. Jurna Akuntabilitas Manajemen Pendidikan, Vol 1 No 1 Hal 98-108.

Maysitoh, Agung, D. F., \& Afdal. 2018. Pendidikan Kejuruan di Era Industri 4.0 : Tantangan dan Peluang Karier. Indonesian Journal Of School Counseling, Vol 3 No 3 Hal 89-96.

Minarti, S. 2017. Manajemen Sekolah: Mengelola Lembaga Pendidikan Secara Mandiri. Yogyakarta: AR-RUZZ Media.

Moleong, L. J. 2010. Metode Penelitian Kualitatif. Bandung: PT Remaja Rosdakarya.

Muhammad, S., \& Rahman, M. 2017. Implementasi Manajemen Berbasis Sekolah Untuk Meningkatkan Mutu Sekolah Dasar Islam Insan Kamil Bacan Kabupaten Halmahera Selatan. Jurnal Pendidikan, Vol 15 No 1, Hal 610-620.

Peraturan Pemerintah No. 19 Tahun 2005 tentang Standar Nasional Pendidikan

Perdana, N. S. 2019. Ketercapaian Sekolah Berasrama Dalam Upaya Peningkatan Mutu dan Akses Pendidikan Achievements School Of Relationship In Efforts To Improve Quality And Access Of Education. Jurnal Edutech, Vol 18 No 2 Hal 219-237. 
Priansa, D. J. 2015. Manajemen Perkantoran Efektif, Efisien, dan Profesional. Bandung: Alfabeta.

Rahayu, S. M., \& Sutama. 2015. Pengelolaan Sarana dan Prasarana Pendidikan Sekolah Menengah Pertama. Jurnal Pendidikan, Vol 27 No. 2 Hal 123-129.

Savitri, A. 2019. Revolusi Industri 4.0 Mengubah Tantangan Menjadi Peluang di Era Revolusi Industri 4.0. Yogyakarta: Genesis.

Sedana, I. M. 2019. Guru Dalam Peningkatan Profesional Agen Perubahan dan Revolusi Industri 4.0. Jurnal Penjaminan Mutu, Vol 5 No 2 Hal 179-189.

Sugiono. 2012. Memahami Penelitian Kualitatif. Bandung: CV Alfabeta .

Sugiono. 2015. Metode Penelitian Kombinasi (Mixed Methods). Bandung: CV Alfabeta.

Suryani. 2017. Manajemen Sarana Prasarana dan Prestasi Belajar Peserta Didik. Jurnal Kependidikan Islam, Vol 7 No 2 Hal 158-174.

Tanggela, M. 2013. Analisis Implementasi Kebijakan Pengelolaan Sarana dan Prasaran Sekolah di SMP Negeri 2 Batu. Jurnal Kebijakan dan Pengembangan Pendidikan, Vol 1 No 1 Hal 26-34.

Umiarso, \& Gojali, I. 2010. Manajemen Sekolah Mutu di Era Otonomi Pendidikan. Yogyakarta: IRCiSoD.

Yulianti, Y., \& Saputra, D. S. 2019. Pelajaran Saint di Era Revolusi Industri 4.0. Jurnal Cakrawala Pendas, Vol 5 No 2, Hal 167-171. 